\section{MR-undersøkelse etter traumatisk hjerneskade}

Etter moderat og alvorlig traumatisk hjerneskade bør det tidlig gjøres klinisk MR-unders økelse for å unngå at man overser forandringer som kan være viktige for prognose og rehabiliteringsforløp.

Pasienter med moderat og alvorlig hjerneskade vil etter skaden ofte ha varierende grad av funksjonsnedsettelse. Det kan skyldes utfall sensorimotorisk, kognitivt, emosjonelt og/eller sosiale forhold. Tidligst mulig estimering av prognose og rehabiliteringspotensial vil være viktig både $\mathrm{i}$ et pasient-, pårørende- og samfunnsperspektiv.

I mitt doktorgradsarbeid har vi ved bruk av ulike MR-sekvenser sett på hvordan direkte og indirekte tegn på skade kan avdekkes hos pasienter med moderat og alvorlig hjerneskade. Etter hjerneskaden ble pasientene fulgt opp med MR-undersøkelse både i tidlig fase (fra innkomstdag og til og med uke 4) og i senere faser (etter tre og 12 måneder). Man fulgte utviklingen og knyttet forandringene som ble funnet i ulike deler av hjernen opp mot pasientens prognose ett år etter skaden.
Vi fant at ikke-blødende traumatiske forandringer forsvant på klinisk MR i løpet av de første tre måneder, men at det var disse skadene som hadde størst betydning for prognosen på sikt. Dersom forandringene ble funnet i dypere deler av hjernen (som hjernebjelke, hjernestamme og thalamus), så de ut til å ha stor betydning for hvordan pasienten klarte seg.

Den kliniske implikasjonen av studiene er at klinisk MR-undersøkelse etter traumatisk hjerneskade bør gjøres så tidlig som pasientens kliniske tilstand tillater det - dette for best mulig å avdekke forandringer som kan ha viktig prognostisk betydning og være av betydning for planlegging av rehabiliteringsforløpet.

\section{Kent Gøran Moen}

kent.g.moen@ntnu.no

\title{
Biomekaniske studier av fikserte lårhalsbrudd
}

\section{Stabiliteten etter skrueosteosyntese av lårhalsbrudd bedres noe ved å låse skruene sammen i en lateral støtteplate.}

Kun $40 \%$ av pasienter med lårhalsbrudd oppnår sitt tidligere funksjonsnivå. Årsakene til redusert funksjon er blant annet smerte og endret biomekanikk i hoften. Begge disse faktorene er relatert til osteosyntesen.

I mitt doktorgradsarbeid har vi evaluert skrueosteosyntese med eller uten en ny låseplate for fiksering av lårhalsbrudd uten feilstilling. Eksperimentene ble utført i humane kadaverbein ved bruk av en hoftesimulator bygd for å gjenskape belastningen over hofteleddet. Låseplaten reduserte både deformasjon av knokkelen og mikrobevegelser over frakturen. Likevel så vi at forbedringen var så liten at det er usikkert om bruk av låseplate vil ha noen klinisk betydning. Våre studier tyder på at egenskaper ved selve knokkelen er viktigere enn valg av implantat for å bevare hoftens biomekanikk.

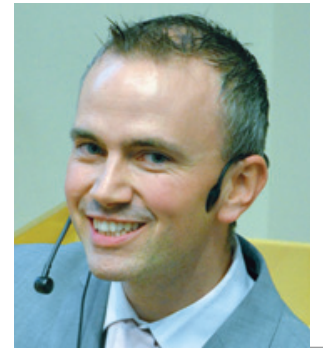

Kent Gøran Moen Foto: Jan Robert Moen

Disputas

Kent Gøran Moen disputerte for ph.d.-graden ved Norges teknisk-naturvitenskapelige universitet 26.9. 2014. Tittelen på avhandlingen er Traumatic axonal injury in traumatic brain injury: conventional and advanced MR from early to chronic phase and relation to outcome.

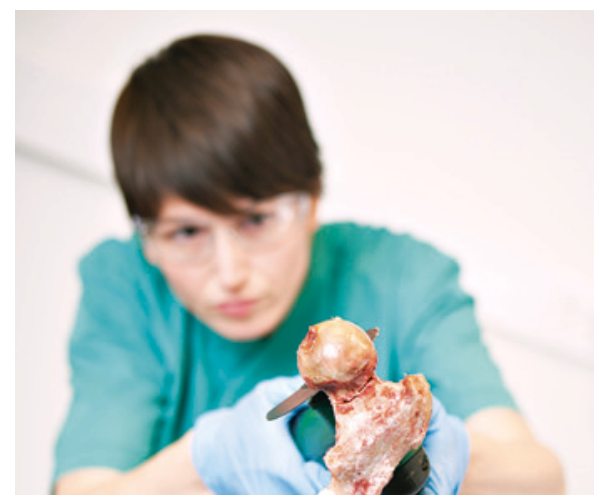

Trude Basso. Foto: Geir Mogen

Disputas

Trude Basso disputerte for ph.d.-graden ved Norges teknisk-naturvitenskapelige universitet 17.10. 2014. Tittelen på avhandlingen er Internal fixation of fragility fractures of the femoral neck, ex vivo biomechanical studies. 